\title{
PRINCÍPIO DA CELERIDADE X PRINCÍPIO DA SUBSIDIARIEDADE NOS JUIZADOS ESPECIAS E OS EFEITOS DO PANPRINCIPIOLOGISMO
}

\author{
Fernanda Patrícia Lima de Oliveira Pucci* \\ Renata Albuquerque Lima*
}

Resumo: O presente artigo se propõe a fazer uma análise crítica da opção jurisprudencial pela não aplicação nos Juizados Especiais da norma relativa à contagem de prazo em dias úteis presente no Novo Código de Processo Civil, fundamentada pelo princípio da celeridade. A partir de pesquisa bibliográfica, análise da legislação e jurisprudência, buscar-se-á no trabalho criticar o papel do julgador solipicista, tecendo comentários sobre a errônea compreensão teórica das regras de interpretação, da prática do sincretismo metodológico e do incorreto sopesamento de princípios, que rompe com o Estado Democrático de Direito, causando grave prejuízo à segurança jurídica.

Palavras-Chave: Juizados Especiais. Panprincipiologismo. Ativismo. Hermenêutica. Decisionismo.

\section{PRINCIPLE OF EXPEDIENCY X PRINCIPLE OF SUBSIDIARITY IN SPECIAL COURTS AND THE EFFECTS OF PANPRINCIPIOLOGISM}

Abstract: The present article proposes to make a critical analysis of the jurisprudential option for the non-application in the Special Courts of the rule regarding the counting of term in working days present in the New Code of Civil Procedure, based on the principle of celerity From a bibliographical research, in addition to an analysis of legislation and jurisprudence, the paper will seek to criticize the role of the solipicist judge, commenting on the erroneous theoretical understanding of the rules of interpretation, the practice of methodological syncretism and the incorrect weighting of principles, which breaks with the Democratic State of Law, causing serious prejudice to legal certainty.

Keywords: Special Courts. Panprincipiologism. Activism. Hermeneutics. Decisionism.

\section{INTRODUÇÃO}

\footnotetext{
"Mestranda em Direito pelo Centro Universitário Christus (UNICHRSTUS). Especialista em Processo Penal na Escola Superior da Magistratura do Estado do Ceará (ESMEC). Graduada em Direito pela Unifor. Advogada. Email: fppucci@gmail.com. ORCID: https://orcid.org/0000-0002-2848-3900

*** Pós-Doutora em Direito pela Universidade Federal de Santa Catarina - UFSC. Doutora em Direito Constitucional pela Universidade de Fortaleza - UNIFOR. Mestre em Direito Constitucional pela Universidade Federal do Ceará - UFC. Graduada em Direito pela UFC e em Administração de Empresas pela UECE. Professora do Programa de Pós-Graduação (Mestrado) da UNICHRISTUS. Professora Adjunta do Curso de Direito da Universidade Estadual Vale do Acaraú - UVA. Coordenadora do Curso de Direito da Faculdade Luciano Feijão - FLF. Advogada. E-mail: realbuquerque@yahoo.com. ORCID: https://orcid.org/0000-00024019-9558.
} 
O novo Código de Processo Civil (Lei ${ }^{\circ}$ 13.105/2015) estabeleceu a contagem dos prazos processuais em dias úteis, em contraposição à disposição do antigo texto processual que estipulava a contagem em dias corridos.

Após o advento da nova lei processual, uma desnecessária celeuma foi criada nos tribunais pátrios relacionada à aplicabilidade da nova norma processual no âmbito dos Juizados Especiais, que, sob o véu do critério informador da celeridade ou princípio da celeridade, foi declarada incompatível com o Sistema dos Juizados Especiais, sendo objeto de enunciado no Fórum Nacional de Juizados Especiais (FONAJE), orientando a não-aplicação da norma, mantendo-se a contagem do prazo em dias corridos, baseados nos princípios que orientam os Juizados Especiais (celeridade, informalidade, etc.) e imersos no universo "panprincipiológico". 1

Embora a Lei 9.099/1995 não possua expressa orientação de supletividade ao Código de Processo Civil naquilo em que seja omissa, o CPC/2015 trouxe o art. 1.046, § $2^{\circ}$, segundo o qual "Permanecem em vigor as disposições especiais dos procedimentos regulados em outras leis, aos quais se aplicará supletivamente este Código", o que fundamenta a aplicação supletiva do CPC à Lei 9.099/1995 e a simples interpretação sistemática permitiria a harmonização do sistema, nos diversos diplomas e suas normas para que não se contradigam, de modo que deve prevalecer e buscar uma interpretação capaz de conciliar o sistema.

Dessa forma, observa-se que, sob a sombra do panprincipiologismo, o Poder Judiciário, numa atuação exacerbadamente ativista, vem transformado o direito brasileiro, usurpando a competência do Legislativo, a despeito do que nela está escrito e das regras técnicas de interpretação de texto e de hermenêutica jurídica. Não se pode esquecer que o ordenamento jurídico é um todo uno que deve harmonizar-se para que as normas possam efetivamente cumprir o papel a elas reservado de estabelecer e vincular condutas. A situação delineada é uma demonstração dos efeitos assustadores do denominado panprincipialismo e seu emprego de forma a violar o Estado Democrático de Direito, em destaque, contra os

$1 \quad$ O panprincipiologismo constitui-se de uma prática interpretativa fomentada por intermédio da hermenêutica neoconstitucionalista, que permite a "criação" de novos princípios desprovidos de força normativa e sem historicidade do direito. Surge como uma patologia ligada às práticas jurídicas brasileira. O termo panprincipialismo foi cunhado por Lenio Streck para fazer referência ao abuso principiológico que se vivencia em terra brasilis ou um álibi para decisões que ultrapassem os próprios limites semânticos do texto constitucional. (STRECK, 2009) 
postulados da ampla defesa, legalidade, tripartição dos poderes, segurança jurídica e devido processo legal.

O presente artigo pretende então questionar o papel dos princípios na atuação jurisdicional e das consequências desse fenômeno na interpretação do direito, que surge como um campo fértil para o abuso da discricionariedade judicial.

Assim, no primeiro momento, será realizado um estudo acerca da controvérsia e das razões e motivos da escolha judicial para a alteração legislativa, buscando fazer uma crítica da utilização de uma justificação principiológica apartada da hermenêutica constitucional e suas consequências e escolha do panprincipialismo como pedra fundamental de interpretação do Poder Judiciário para resolução das controvérsias.

Destaque-se ainda que o tema em questão foi enfrentado por meio de pesquisa bibliográfica, com suporte em livros, artigos, bem como análise de legislação e jurisprudência sobre o assunto. Acerca dos objetivos propostos, esta pesquisa foi delineada como descritiva documental.

\section{BREVE HISTÓRICO DO NOVO SISTEMA PROCESSUAL CIVIL E A SUA APLICAÇÃO CONTROVERTIDA NOS TRIBUNAIS}

O novo Código de Processo Civil fomentou importantes mudanças na norma processual vigente, refletindo uma evolução metodológica representada pelo neoprocessualismo, com o fim de conferir máxima efetividade ao processo. Entre as mudanças implementadas, adveio a alteração da forma da contagem dos prazos processuais, passando a ser computada em dias úteis, ganhando destaque o questionamento sobre a compatibilidade desta com os Juizados Especiais, especialmente no suposto confronto com o princípio orientador da celeridade, tendo em vista a especificidade do sistema.

Vale lembrar que a nova lei processual foi elaborada com a promessa de tornar o processo civil mais adequado, tecendo como objetivos: 1) estabelecer expressa e implicitamente verdadeira sintonia fina com a Constituição Federal; 2) criar condições para que o juiz possa proferir decisão de forma mais adequada à realidade fática subjacente à causa; 3) simplificar, resolvendo problemas e reduzindo a complexidade de subsistemas, como, por exemplo, o recursal, dar todo o rendimento possível a cada processo em si mesmo considerado; e, 5) finalmente, sendo talvez este último objetivo parcialmente alcançado pela 
realização daqueles mencionados antes, imprimir maior grau de organicidade ao sistema, dando-lhe, assim, mais coesão, e que sem dúvidas veio como a concretização e reconhecimento do direito essencial do advogado e o direito ao descanso (ALVES, 2016).

A Lei $n^{\circ} 9.099 / 95$ surgiu para regulamentar a procedimentalização do microssistema dos Juizados Especiais, fruto do mandamento constitucional, advindo do inciso I do artigo $98^{2}$ da Constituição Federal de 1988. Seu surgimento ocorreu sete anos após a promulgação da Constituição Federal, demandando esforço e tempo legislativo, erguendo a bandeira do processo efetivo, associado às garantias de prestação constitucional e acesso à justiça. A referida lei contém em seu núcleo princípios norteadores que a diferenciam do procedimento comum, sendo, por vezes, embasadora de questionamentos relativos à compatibilidade entre ela e a norma processual.

Com o advento da nova norma processual, tornou-se assídua a divergência entre os Tribunais dos Estados quanto à forma de contagem do prazo processual, ante a subsidiariedade da aplicação da norma processual ao sistema dos Juizados Especiais, baseada no fato de que aparentemente a contagem dos prazos processuais feriria os princípios que orientam o sistema, sobretudo, o princípio da celeridade. Tal situação se agravou pela edição do enunciado n. 165 do Fonaje e do enunciado n. 13 dos Juizados da Fazenda Pública, que recomendaram o desatendimento à nova regra processual da contagem dos prazos, considerando como fundamento fulcral, a força supralegal do Princípio da Celeridade no âmbito dos Juizados Especiais, em contraponto à subsidiariedade da norma processual.

\footnotetext{
Fórum Nacional dos Juizados Especiais - FONAJE

ENUNCIADO 165 - Nos Juizados Especiais Cíveis, todos os prazos serão contados de forma contínua (XXXIX Encontro - Maceió/AL) (FÓRUM NACIONAL DE JUIZADOS ESPECIAIS, [201?]).
}

Enunciado da Fazenda Pública

ENUNCIADO 13 - A contagem dos prazos processuais nos Juizados da Fazenda Pública será feita contínua, observando-se, inclusive a regra especial de que não há prazo diferenciado para a Fazenda Pública - Art. $7^{\circ}$ da Lei 12.153/90 (CONSELHO NACIONAL DE JUSTIÇA, [201?]).

2 Art. 98. A União, no Distrito Federal e nos Territórios e os Estados criarão: I - juizados especiais, providos por juízes togados e leigos, competentes para a conciliação, o julgamento e a execução de causas cíveis de menor complexidade e infrações penais de menor potencial ofensivo, mediante os procedimentos oral e sumaríssimo, permitidos, nas hipóteses previstas em lei, a tramitação e o julgamento de recursos por turmas de juízes de primeiro grau (BRASIL, 1995). 
O referido entendimento foi perfilado pelo Conselho Nacional de Justiça quando anunciou apoio à Nota Técnica 1/16 do Fórum Nacional dos Juizados Especiais ${ }^{3}$ (FONAJE), considerando que, a adoção da nova regra de contagem de prazos prevista no novo CPC, atentava contra os princípios fundamentais dos processos, analisados pelos Juizados Especiais, como a simplicidade, a economia processual e, sobretudo, a celeridade ${ }^{4}$.

FORUM NACIONAL DE JUIZADOS ESPECIAIS - FONAJE - NOTA TÉCNICA N. 01/2016 - Ref.: Artigo 219 do Código de Processo Civil de 2015, que trata da contagem de prazos processuais em dias úteis: Os Magistrados integrantes da Diretoria e Comissões do FONAJE - Fórum Nacional de Juizados Especiais, reunidos ordinariamente, nas dependências do Tribunal de Justiça do Estado de Santa Catarina, na cidade de Florianópolis, em data de 04 de março de 2016, convictos de que as disposições do artigo 219 do Novo CPC, relativas à contagem de prazos processuais, não se aplicam ao Sistema de Juizados Especiais, deliberaram por elaborar e divulgar a presente Nota Técnica, já como indicativo de proposta de enunciado específico a ser apreciada por ocasião do XXXIX Encontro do FONAJE, a ter lugar em Maceió-AL, de 08 a 10 de junho de 2016, dada a flagrante incompatibilidade com os critérios informadores da Lei 9.099/1995. O legislador de 1995, ao conceber os Juizados Especiais Cíveis e Criminais e discipliná-los por via da Lei 9.099, alinhou, em seu artigo $2^{\circ}$, os critérios informadores sob os quais deverá se orientar o processo neste especial ramo de jurisdição, quais sejam o da oralidade, simplicidade, informalidade, economia processual e, destacadamente ao que interessa à presente Nota Técnica, o da celeridade. Desde sua entrada em vigor, a Lei 9.099 veio convivendo com o CPC de 1.973 sem que o procedimento nela estatuído sofresse influências da lei processual comum codificada, posto sustentar-se esta em princípios absolutamente inconciliáveis com os aludidos critérios informadores. Estabeleceu-se, assim, a convicção de que as disposições codificadas não se aplicam ao rito dos processos que tramitem em sede de Juizados Especiais Cíveis em sua fase de conhecimento, mas tão só - e no que couber - à fase de execução (cumprimento) de sentença, assim como, subsidiariamente, à execução de título extrajudicial. Consabidamente, não há prazos legais previstos pela Lei 9.099 para a fase de conhecimento, de modo que todos os prazos são judiciais. A única exceção é relativa ao Recurso Inominado, para o qual prevê o prazo de 10 dias. E todos esses prazos sempre foram contados em dias corridos, mesmo porque, até 2015, não se conhecia no ordenamento jurídico brasileiro nenhuma outra lei adjetiva que contemplasse algum método diverso de cômputo. Com o advento do Novo Código de Processo Civil (CPC de 2015), por força do artigo 219, a justiça cível dita comum passa a conviver com a contagem de prazos legais e judiciais em dias úteis, em inexplicável distanciamento e indisfarçável subversão ao princípio constitucional da razoável duração do processo. Todavia, forçoso é concluir que a contagem ali prevista não se aplica ao rito dos Juizados Especiais, primeiramente pela incompatibilidade com o critério informador da celeridade, convindo ter em mente que a Lei 9.099 conserva íntegro o seu caráter de lei especial frente ao Novo CPC, desimportando, por óbvio, a superveniência deste em relação àquela. Não bastasse esse argumento, cumpre não perder de vista que o legislador de 2015, em alguns poucos artigos, fez remissão expressa aos Juizados Especiais, disciplinando, modo cogente, a aplicação desses dispositivos da lei processual comum ao procedimento regulado pela Lei 9.099. A melhor técnica de hermenêutica jurídica leva, necessariamente, à conclusão de que, assim agindo, o legislador quis limitar, numerus clausus, àquelas hipóteses, as influências do CPC sobre o sistema dos juizados, ciente das implicações prejudiciais decorrentes de uma maior ingerência legal que porventura houvesse, claramente contra os interesses do jurisdicionado que acorre aos juizados. Inclusio unius est exclusio alterius. Por outro lado, em seu XXXVIII Encontro, realizado em Belo Horizonte-MG, em novembro de 2015, o FONAJE, antecipando-se, expediu enunciado em que se subssume a questão dos prazos, v.g., "Considerando o princípio da especialidade, o CPC/2015 somente terá aplicação ao Sistema dos Juizados Especiais nos casos de expressa e específica remissão ou na hipótese de compatibilidade com os critérios previstos no art. $2^{\circ}$ da Lei 9.099/95." Postas tais considerações, o FONAJE externa a sua posição pela inaplicabilidade do artigo 219 do CPC/2015 aos Juizados Especiais, da mesma forma que não se aplica ao Processo do Trabalho (art. 775 da CLT) e ao Processo Penal (art. 798 do CPP) [...] (FÓRUM NACIONAL DE JUIZADOS ESPECIAIS, [201?]).

$4 \quad$ Em defesa da razoável duração desses processos, Nancy Andrighi manifesta seu total apoio à Nota Técnica 1/16 do Fórum Nacional dos Juizados Especiais (Fonaje). O documento pede a inaplicabilidade do artigo 219 do novo CPC aos Juizados Especiais.

Revista Cidadania e Acesso à Justiça | e-ISSN: 2526-026X | Porto Alegre | v. 4 | n. 2 | p. 96 - 115 | 
O Fórum Permanente de Processualistas Civis (FPPC), por sua vez, pronunciou-se pela aplicabilidade do artigo 219, do Código de Processo Civil, editando o Enunciado ${ }^{\circ} 416$ : "A contagem do prazo processual em dias úteis se aplica aos Juizados Cíveis, Federais e da Fazenda Pública” (CONSELHO DA JUSTIÇA FEDERAL, 2017).

Como consequência da divergência interpretativa, os tribunais pátrios apresentaramse divididos quanto à aplicação da norma, criando um ambiente jurídico volátil, dando margem à insegurança jurídica. Cumpre referenciar que os Tribunais de Justiça do Amapá, Ceará, Bahia, Sergipe, Rio Grande do Norte, Mato Grosso, Pernambuco, Piauí, Paraná, Maranhão, Acre, São Paulo, Alagoas, Rio de Janeiro, Paraíba, Espírito Santo e Mato Grosso do Sul adotam a regra de dias corridos em seus Juizados Especiais, enquanto os Tribunais de Justiça dos Estados de Santa Catarina, Tocantins, Rondônia, Roraima, Rio Grande do Sul, Pará, Amazonas e Distrito Federal e Territórios aplicam a contagem conforme a orientação constante do art. 219 do Código de Processo Civil, posição replicada pelos Tribunais Regionais Federais da $1^{\mathrm{a}}, 2^{\mathrm{a}}, 3^{\mathrm{a}}, 4^{\mathrm{a}}$ e $5^{\mathrm{a}} .^{5}$

A divergência, no entendimento, gerou uma dissonância na jurisprudência dando cabo à impetração pela Ordem dos Advogados do Brasil, da ADPF 483, que está em trâmite no Supremo Tribunal Federal e que questiona a violação aos preceitos fundamentais constitucionais, como o princípio da segurança jurídica ${ }^{6}$, o devido processo legal e o acesso à justiça, decorrente da adoção da contagem processual ininterrupta pelas autoridades judiciárias.

Em manifestação na citada ADPF, a Procuradoria Geral da União considerou que a postura judicial de afastar a incidência da norma no caso concreto sem que sua

5 ADPF 483. O Conselho Federal da Ordem dos Advogados do Brasil (OAB) ajuizou no Supremo Tribunal Federal a Arguição de Descumprimento de Preceito Fundamental (ADPF) 483, na qual sustenta a inconstitucionalidade de decisões judiciais que aplicam a contagem dos prazos em dias corridos e pede que o STF determine que os prazos processuais sejam contados em dias úteis. Segundo a OAB, viola preceitos constitucionais fundamentais, como o da ampla defesa, da legalidade, da tripartição dos poderes, da segurança jurídica, do devido processo legal e do direito ao repouso semanal (no caso, dos operadores do Direito). No pedido de liminar, no sentido de determinar que seja imediatamente adotada a contagem dos prazos em dias úteis nos processos em tramitação nos juizados especiais nas três esferas, a entidade de classe fundamenta a urgência sobretudo em razão de que os prazos processuais, caso descumpridos, "acarretam perecimento de direitos", e sua supressão indevida caracteriza cerceamento da plenitude do direito à ampla defesa. Em despacho inicial o Ministro relator Luiz Fux determinou a requisição de informações aos Tribunais Regionais Federais e aos Tribunais de Justiça estaduais e após, que os autos fossem remetidos ao Advogado-Geral da União e ao Procurador-Geral da República, para manifestação. Em 02/08/2018 o processo encontra-se com vista à PGR desde 05/02/5018 (SUPREMO TRIBUNAL FEDERAL, 2017).

6 Princípio da segurança jurídica - art. $5^{\circ}$, inciso XXXVI, da Constituição de 1988 (BRASIL, 1988).

Revista Cidadania e Acesso à Justiça | e-ISSN: 2526-026X | Porto Alegre | v. 4 | n. 2 | p. 96 - 115 | 
inconstitucionalidade tenha sido declarada, fragiliza a segurança jurídica e reforça a imprevisibilidade no sistema de justiça, além de afrontar a divisão de funções estabelecida pelo constituinte. Assevera ainda que a criação judicial de regra destituída de amparo legal e incompatível com comando expresso em lei validamente elaborada pelo legislador invade a esfera de atuação dos Poderes Legislativo e Executivo, ofendendo aos artigos $2^{\circ}$ e $5^{\circ}$, inciso II, da Constituição de 1988, ao mesmo passo que a constitui afronta ao devido processo legal o descumprimento do rito processual legalmente estabelecido, com prejuízo para o exercício adequado dos direitos ao contraditório e à ampla defesa.

Por fim, e apenas após a impetração da ADPF 483, a temática fomentou debate na Primeira Jornada de Direito Processual Civil, realizada pelo Superior Tribunal de Justiça e Conselho Nacional de Justiça, em agosto de 2017, onde foi levantada proposta para a convergência dos entendimentos e aplicabilidade da nova regra processual no sistema dos Juizados Especiais, surgindo o Enunciado $\mathrm{n}^{\circ}$ 19, do Conselho de Justiça Federal (2017): "prazo em dias úteis previsto no art. 219, do CPC aplica-se também aos procedimentos regidos pelas Leis n. 9.00/95, 10.259/2001 e 12.153/2009”.

Somente em outubro de 2018 foi solucionada a questão, antes mesmo do julgamento da mencionada ADPF, o que se deu por meio da Lei no 13.728, de 31 de Outubro de 2018 que alterou a Lei $\mathrm{n}^{\circ}$ 9.099, de 26 de setembro de 1995, para estabelecer que, na contagem de prazo para a prática de qualquer ato processual, inclusive para a interposição de recursos, serão computados somente os dias úteis.

Pode-se verificar que a grave questão de fundo da situação acima foi decorrência dos efeitos do panprincipiologismo no direito contemporâneo, desmascarando uma verdadeira crise hermenêutica da forma de se pensar o papel dos princípios no cenário jurídico brasileiro, evidenciando a discricionariedade dos julgadores e a criação pessoal e ideológica de pseudo ou mesmo de superprincípios, em detrimento da coerência e integridade do ordenamento jurídico brasileiro.

O afastamento da incidência do artigo 219 da Lei ${ }^{\circ} 13.105 / 2015$ no sistema dos Juizados Especiais, mesmo que temporário, não se justifica. Ademais, é norma cogente por decisão do legislador federal, prevista no artigo 27, da Lei $\mathrm{n}^{\circ} 12.153 / 2009$, que determina a aplicação subsidiária do Código de Processo Civil e o enunciado acima corrobora com o 
entendimento de que a lacuna legislativa citada requer a aplicação supletiva do Código de Processo Civil.

Embora a Lei 9.099/1995 não contenha dispositivo que oriente a supletividade do Código de Processo Civil, o novo CPC (BRASIL, 2015) trouxe o art. 1.046, § $2^{\circ}$, que prescreve que "Permanecem em vigor as disposições especiais dos procedimentos regulados em outras leis, aos quais se aplicará supletivamente este Código", o que assegura a aplicação supletiva do CPC à Lei 9.099/1995. No entanto, antes mesmo da nova norma processual deveria ter-se observado o que prescreve a Lei de Introdução às Normas do Direito Brasileiro (Decreto Lei n. 4.657/1942) (BRASIL, 1942) que estatui que "Quando a lei for omissa, o juiz decidirá o caso de acordo com a analogia, os costumes e os princípios gerais de direito”, sendo, ademais, desnecessária a edição de novo preceito legal para que se compreenda a legalidade da regra da contagem de prazos.

Assim, verifica-se que a simples interpretação sistemática fomentaria a harmonização dos diversos diplomas e suas normas, de modo a prevalecer a interpretação capaz de conciliar uma norma com outra, um diploma com outro, preservando a harmonia do ordenamento jurídico.

\section{PRINCÍPIO DA CELERIDADE VERSUS PRINCÍPIO DA SUBSIDIARIEDADE: OS MOTIVOS PARA O AFASTAMENTO DA NOVA NORMA PROCESSUAL}

No Estado democrático contemporâneo, a eficácia concreta dos princípios constitucionais e legalmente assegurados depende da garantia da tutela jurisdicional efetiva, porque sem ela, o titular do direito não dispõe da proteção necessária do Estado em seu pleno gozo. A tutela jurisdicional efetiva é, portanto, não apenas uma garantia, mas, ela própria, também um direito fundamental, cuja eficácia irrestrita é preciso assegurar, em respeito à própria dignidade humana. O Direito Processual procura disciplinar o exercício da jurisdição através de princípios e regras que confiram ao processo a mais ampla efetividade, ou seja, o maior alcance prático e o menor custo possível na proteção concreta dos direitos dos cidadãos. (GRECO, 2016).

Considerando o objeto da garantia da tutela jurisdicional efetiva, compreende-se a inserção do princípio da celeridade, como marco orientador dos Juizados Especiais. A celeridade constitui-se de grande importância dentro do sistema, na medida em que figura

Revista Cidadania e Acesso à Justiça | e-ISSN: 2526-026X | Porto Alegre | v. 4 | n. 2 | p. 96 - 115 | 
como elemento diferenciador nato entre o procedimento dos Juizados Especiais e aqueles que transitam na Justiça Comum.

No entanto, apesar da importância e destaque da celeridade para todo o sistema dos juizados, não se pode compreender que sua aplicação seja o único objeto a ser defendido, mesmo que, para isso, seja sacrificada a segurança jurídica e o devido processo legal. Assim, indaga-se: Pode-se suplantar a ordem processual e o devido processo legal em nome da rapidez na prestação jurisdicional? Será que a mudança da forma da contagem do prazo é realmente a causa da ineficácia e demora da prestação jurisdicional?

Certamente a resposta é negativa, contudo, adentrar-se-á nas questões que orientaram o entendimento da inaplicabilidade da nova regra processual.

Nas lições de Veloso Peleja Júnior e Humberto Santarosa de Oliveira (2015), os vetores dos juizados visam possibilitar aos cidadãos o amparo jurisdicional para dirimir problemas cotidianos não interessantes à morosa jurisdição ordinária, e isto é realizado por meio de procedimentos simplificados e rápidos, com foco na resolução amistosa do conflito, é corolário da cidadania democrática e compreendem a celeridade como manifesta atuação rápida do Poder Judiciário com a entrega da prestação jurisdicional em tempo diminuto. $\mathrm{O}$ objetivo é a prática otimizada dos atos processuais, evitando-se os "prazos mortos", que em muito contribuem para a morosidade.

É compreensível a preocupação com a morosidade e como o engessamento de institutos que findem por prejudicar a simplicidade, no entanto, uma busca cega pela celeridade poderá vir a ferir garantias processuais constitucionalmente asseguradas, uma vez que a rapidez, por si só, não se justifica.

De forma, dentre um dos argumentos utilizados pela doutrina, pode-se citar aquele que se extrai do pensamento Vilian Bollmann (2016):

[...] o novo CPC não afirma a sua aplicabilidade com relação aos Juizados Especiais. Ao contrário: ele inicia indicando a supremacia da Constituição com relação ao trato do processo civil, observando-se as normas do Código (art. $1^{\circ}$ ) e, mais adiante, complementa apontando ser aplicável supletiva e subsidiariamente nos processos eleitorais, administrativos e trabalhistas (art. 15). Logo embora podendo, o legislador em nenhum momento previu expressamente a sua aplicação os juizados.

Como se verifica, sustenta-se que tanto pela celeridade, quanto pela inexistência de subsidiariedade que o novo Código de Processo Civil não se aplicaria nos juizados, permanecendo viva a contagem de prazos em dias corridos. No entanto, o discurso da

Revista Cidadania e Acesso à Justiça | e-ISSN: 2526-026X | Porto Alegre | v. 4 | n. 2 | p. 96 - 115 | 
morosidade imputada aos prazos e a lentidão que assola o trâmite processual não justifica para afastamento da norma constitucional. Em verdade, sabe-se que os problemas da morosidade e da lentidão do Judiciário vão além dos prazos, e incluem problemas organizacionais, operacionais, materiais, pessoais, além do tempo morto do processo, quando os processos permanecem meses a fio parados nos escaninhos físicos e virtuais da justiça, não podendo ser a contagem dos prazos, razão em si para justificar a falta de efetividade da prestação jurisdicional.

Não é o fato de os Juizados Especiais serem regidos por legislação especial que os juízes gozariam de liberdade para poder afastar a norma posta. Ao contrário, a nova regra processual de contagem de prazo expressa, na sua completude, a valoração do sistema e dos princípios do devido processo constitucional, que prescreve, dentre outros, a proteção do princípio da razoável duração do processo.

O Código de Processo Civil foi elaborado com novos princípios e novas propostas, com base no neoconstitucionalismo e nas premissas do processo constitucional democrático, tendo os prazos, como conceito, a compreensão de que correspondem ao interregno de tempo possível para a atuação dos sujeitos (MARINONI; MITIDIERO, 2015)

O tempo devido do processo somente pode ser aferido diante do caso concreto, não podendo a duração razoável do processo ser confundida com celeridade. Numa crítica à visão instrumentalista, focada na socialização do direito preocupada apenas com a celeridade dos procedimentos, mostrando-se como um modelo de processo esgotado e incapaz de enfrentar os desafios do processo democrático, nos cabe relatar os ensinamentos de Carlos Marden (2015, p. 203):

Para superar estes obstáculos e promover uma leitura do conceito de duração razoável do processo, impõe-se, já num primeiro momento, o abandono da matriz teórica da Escola Instrumentalista do Processo em favor da adoção do conceito de modelo constitucional de processo como sendo o novo marco teórico a ser utilizado. Passa-se então, a entender que existe um direito fundamental ao processo enquanto metodologia de garantia de direitos fundamentais; sendo que o processo a ser configurado e assegurado deve necessariamente ser organizado com base na ideia de que os direitos fundamentais processuais (duração razoável/ampla defesa/argumentação, contraditório, imparcialidade e fundamentação das decisões) formam uma base principiológica harmônica e uníssona. [...] Sendo assim, pode-se usar o conceito de Giacomo Marramao ao afirmar que a duração razoável do processo (kairológico) é o tempo do devido processo constitucional como forma de dizer que o modelo constitucional de processo vai fornecer os elementos para que, em cada caso concreto, se estabelece uma janela de tempestividade, dentro da qual a duração do processo pode ser considerada razoável. Em outras palavras: o processo não pode ser tão demorado que venha a comprometer a sua efetividade e/ou gerar

Revista Cidadania e Acesso à Justiça | e-ISSN: 2526-026X | Porto Alegre | v. 4 | n. 2 | p. 96 - 115 | 
prejuízo para as partes, nem poderia ser tão apressado que não seja permitido às partes o exercício de seus direitos fundamentais processuais.

Assim, percebe-se que o equilíbrio entre celeridade e segurança jurídica é o que busca o processo efetivo sob a influência do princípio da razoável duração do processo. Nas palavras de José Maria de Melo e Mário Parente Teófilo Filho não se deve perder de vista que, acima da celeridade processual, o juizado especial tem que procurar atingir a justiça. A rapidez da tramitação dos feitos, se ele ocorre em prejuízo aos direitos de alguma parte, de nada valerá. (MELO; TEÓFILO NETO, 1997).

De outro lado, partindo para tratativas sobre o princípio da subsidiariedade, verificase que a legislação reguladora dos Juizados (Lei no. 9.099/95) não trazia normas processuais próprias e não tratava expressamente da aplicabilidade subsidiária do Código de Processo Civil, máxima presente na prática e na jurisprudência, desde a edição da Lei n. 9099/95, sendo majoritário o entendimento de que o Código de Processo Civil se aplica subsidiariamente ao sistema dos juizados. Segundo explica Sérgio Niemeyer (2016), tal defectibilidade da lei especial resolve-se com a aplicação da lei geral (LINDB, artigo $2^{\circ}, \S 2^{\circ}$ ), “in casu” a Lei 5.869/1973, o antigo Código de Processo Civil que se harmonizam segundos os preceitos da Lei de Introdução às Normas do Direito Brasileiro (LINDB, decreto-lei 4.657/1942) e, naturalmente, sob a orientação científico-doutrinária da hermenêutica jurídica, a respeito dessa matéria.

A legislação, que versa sobre os Juizados Especiais, embora prescrevesse prazos processuais específicos, como no caso do recurso inominado, não estabelecia forma diferenciada de contagem de prazo e observava os critérios gerais de contagem firmados pela norma processual. Tal aplicação foi recorrência hermenêutica e histórica, desde o advento da Lei $\mathrm{n}^{\circ}$ 9.099/95 e das Leis $\mathrm{n}^{\circ} 10.259 / 2001$ e Lei $\mathrm{n}^{\circ} 12.153 / 2009$. No microssistema dos Juizados Especiais ${ }^{7}$, inexistia regra explícita, que versasse sobre a contagem dos prazos processuais e essa ausência atraia a incidência do Código de Processo Civil, de forma supletiva, disposto no artigo 1.046, $\S 2^{\circ}$, do Código de Processo Civil, impondo a aplicação,

7 Cf. Lei n. 12.153/2009: “Art. $1^{\circ}$ Os Juizados Especiais da Fazenda Pública, órgãos da justiça comum e integrantes do Sistema dos Juizados Especiais, serão criados pela União, no Distrito Federal e nos territórios e pelos Estados, para conciliação, processo, julgamento e execução, nas causas de sua competência. Parágrafo único: O sistema dos Juizados Especiais dos Estados e do Distrito Federal é formado pelos Juizados Especiais Cíveis, Juizados Especiais Criminais e Juizados Especiais da Fazenda Pública” (BRASIL, 2009). 
desde que operacionalizados aos moldes do procedimento comum, desde que com observância aos princípios orientadores.

Ademais, a ausência de procedimento previsto legalmente no âmbito dos juizados dirige o juiz para o caminho do suprimento da lacuna por meio do novo Código de Processo Civil, não encontrando fundamento a defesa da aplicação da norma revogada, Código de Processo Civil de 1973, por compreender apenas uma forçosa interpretação sistemática, frágil e forçada.

Essa interpretação pretendida com a edição do novo Código de Processo Civil, maculada pela influência do panprincipiologismo com o objetivo de transformar o direito brasileiro e estabelecer os critérios próprios de contagem de prazos nos Juizados Especiais Cíveis deveriam ter sido empregados ainda em 1995, quando da edição da Lei dos Juizados para criar critérios distintos até mesmo daqueles previstos no CPC/1973, e não agora, para negar o novo CPC e adotar os critérios regidos por norma processual não mais vigente. Percebe-se que somente por conta dessa inovação na forma da contagem de prazos processual que se fez necessária a edição de nova lei regulando unicamente a contagem de prazo de forma a garantir a proteger a integralidade do sistema.

\section{ATIVIDADE INTERPRETATIVA: CRÍTICA E NECESSIDADE DE RELEITURA}

Para o neoconstitucionalismo, o direito processual supera-se como conceito de conjunto de regras para aplicação do direito material e passa a ser tratado com o instrumento para efetivação da justiça. Assim, o conteúdo constitucional-ideológico do processo se reflete na consagração, por um lado, de normas constitucionais que visam à garantia processual da própria Constituição, e por outro, de garantias constitucionais em relação ao processo e ao procedimento (DANTAS, 2013).

Os princípios ganharam força normativa e o Código de Processo Civil, em harmonia com a Constituição, implementou a socialização do processo, na busca da rapidez, eficácia e simplificação da tutela jurisdicional. E é nesse espírito que deve o julgador se pautar a fim promover a aplicação orientada da norma e dos princípios, sem deixar de lado as garantias constitucionais, como o devido processo legal.

A adoção destacada de princípios, sem a observância desses preceitos afeta, de forma desproporcional, as garantias constitucionais como o direito ao contraditório, prevista no 
inciso LV do artigo $5^{\circ}$. da Constituição Federal. Autores como Eduardo Otieza e Ovídio Baptista descrevem a dificuldade de se equilibrar a busca pela celeridade/efetividade do procedimento com as garantias fundamentais do processo como desafio do milênio para os processualistas (ISAIA, 2014 apud FIALHO, 2017).

Os princípios são compreendidos como a margem de abertura na decisão dos tribunais, contudo, essa atuação jurisdicional deve ocorrer dentro de limites, para que seja possível a legitimação democrática das decisões. Assim, pode-se compreender que os princípios são a mola mestra do ordenamento jurídico, sendo este um sistema dinâmico que interage com a realidade fática e tem a atividade interpretativa como fator de desenvolvimento.

Os princípios permeiam todo o texto normativo, conferindo harmonia, unidade e dinamismo, inexistindo hierarquia entre as normas/regras e as normas/princípios, tendo na atividade interpretativa o meio de extração de seu conteúdo, sentido e alcance para que possa ser aplicada no caso concreto e visa construir o conteúdo normativo da lei, deixando-o explícito, para que possa ser aplicado a determinado caso.

$\mathrm{Na}$ aplicação do direito por um órgão jurídico, a interpretação cognoscível (obtida por uma operação de conhecimento) do direito a aplicar combina-se com um ato de vontade em que o órgão aplicador do direito efetua uma escolha entre as possibilidades reveladas através daquela mesma interpretação cognoscível. Com esse ato, ou é produzida uma norma de escalão inferior, ou é executado um ato de coerção estatuído na norma jurídica aplicada. Através deste ato de vontade se distingue a interpretação jurídica feita pelo órgão aplicador do direito de toda e qualquer outra interpretação, especialmente da interpretação levada a cabo pela ciência jurídica (KELSEN, 2006).

Dessa forma, a atividade interpretativa vai além da mera aplicação de uma norma jurídica, pois assume função de tornar-se um fator de atualização e renovação de toda a ordem jurídica. No entanto, a interpretação não pode e nem deve ser compreendida como atividade ilimitada, mas ela encontra seus limites na própria expressão literal da lei. Note-se que não é permitido o emprego da interpretação com vistas a alterar completamente o sentido da norma constitucional. Esta alteração é proibida, na medida em que modifica a própria vontade da lei, violando flagrantemente a literalidade de seu texto. Ao assim proceder, o intérprete está se 
tornando um legislador positivo - o que é vedado pelo ordenamento jurídico. (BASTOS, 2007).

Pode-se assim compreender que a primeira interpretação dada pela jurisprudência e chancelada pelo CNJ na edição de enunciados que findaram por afastar a aplicação do artigo 219 do novo Código de Processo Civil no sistema dos Juizados Especiais resultou numa interpretação em que o texto da norma é completamente alterado e a vontade da lei violada, criando-se uma nova norma jurídica e, por consequência é uma interpretação que não pode ser empregada.

A modificação dada pela interpretação no referido caso compreendeu uma alteração formal na norma e que certamente feriu o princípio da segurança jurídica. Em decorrência desta situação, indaga-se o porque de em nossos Tribunais, a exemplo da questão aqui posta, utiliza-se as técnicas de interpretação da hermenêutica de forma a causar tanta instabilidade no sistema jurídico? Uma autocrítica deve ser iniciada.

Para Virgílio Afonso da Silva (2005), a problemática gira em torno da confusão doutrinária no Brasil acerca da discussão sobre regras e princípios e do fenômeno denominado sincretismo metodológico, que consiste na adoção de teorias incompatíveis, como se compatíveis fossem, como, por exemplo, na recepção da distinção entre regras e princípios de Robert Alexy (2007) e a chamada Teoria Estruturante do Direito de Müller ${ }^{8}$, que divergem entre si quanto ao sopesamento de princípios como regra de aplicação do direito e, em decorrência disso, surgem graves problemas interpretativos, que impõe uma alteração legislativa desmedida, desconexa e desarrazoada.

Em decorrência dessa situação de difícil abordagem teórica e certamente estrutural no pensamento jurídico e jurisdicional nacional, é que toma força o panprincipialismo, que pode ser observado na atuação dos tribunais brasileiros que revelam uma tendência de desprezo às normas específicas que foram promulgadas pelo legislador, preferindo basear-se diretamente por princípios, como no caso aqui relatado, o da celeridade, para solucionar a

8 A Teoria Estruturante do Direito qualifica como "normativas" todas as circunstâncias capazes de direcionar o processo de decisão, sejam dados de linguagem (textos de normas), sejam dados reais. Assim, normatividade, para a teoria predita, é uma qualidade dinâmica da norma, aferível unicamente na regulamentação de questões jurídicas concretas. [...] O conceito de norma construído a partir da Teoria Estruturante do Direito dá lugar à concretização de todas as espécies de normas jurídicas, especialmente as inerentes a direitos fundamentais. Isso porque a sua aplicação não se limita ao texto normativo, considerando também a dimensão fática e outras condicionantes. Todavia, a predita aplicação encontra limite na norma, que tem a normatividade concreta atrelada ao caso específico. (MÜLLER, 2003).

Revista Cidadania e Acesso à Justiça | e-ISSN: 2526-026X | Porto Alegre | v. 4 | n. 2 | p. 96 - 115 | 
questão posta, mesmo que sua aplicação seja diametralmente contrária ao que a norma específica prescreve, dando um poder maior do juiz sobre o legislador.

Streck (2015), na sua crítica ao panprincipialismo, sempre sustentou a ocorrência do abuso das cláusulas gerais, que é decorrência da equivocada interpretação da jurisprudência dos valores da tese de Robert Alexy (2007), de que princípios são mandados de otimização.

[...] é equivocada a tese de que os princípios são mandatos de otimização e de que as regras traduzem especificidades em caso de colisão, uma afastaria a outra, na base do "tudo ou nada", pois dá a ideia de que os "princípios" seriam "clausulas abertas", espaço reservado à "livre atuação da subjetividade do juiz", na linha, da defesa que alguns civilistas fazem das clausulas gerais do novo Código Civil, que, nesta parte, seria o “Código do juiz”'. (STRECK, 2014, p. 142)

A crítica de Streck traz à tona as situações desagradáveis do sincretismo metodológico e da importação e utilização inadequadas e até contraditórias de teorias e da abertura valorativa principiológica que se espalhou por todos os campos do direito, e o uso desenfreado da ponderação de valores ou de interesses que fomentam um campo fértil para o abuso de autoridade e a discricionariedade judicial.

O autor reforça sua crítica ao afirmar que não se pode converter cada unidade jurisdicional brasileira em uma "microconstituinte" ou nela encontrar um "código particular".

Não se quer aqui defender que os juízes não devem interpretar, longe disso. O que se tenta trazer a discussão é uma crítica à discricionariedade judicial e os seus limites. O que se quer repelir é a atuação do juiz revestida de poderes legislativos e confeccionadores de princípios, normas e jurisprudência de aplicabilidade vinculante, como se fossem os únicos capazes de encontrar o sentido da norma. E esse investimento de juízes de poderes de legislador faz com que se criem institutos teratológicos, como o panprincipiologismo, levando diretamente ao ativismo judicial.

\section{CONCLUSÃO}

O novo Código de Processo Civil foi pensado com a intenção de otimização processual, sendo visto como instrumento a ser utilizado para que se chegue a uma justa e célebre decisão na busca de uma evidente redução da complexidade inerente ao processo com a finalidade de estabelecer expressa e implicitamente verdadeira sintonia com a Constituição Federal, criando condições para que o juiz possa proferir decisão de forma mais rente à 
realidade fática subjacente à causa; simplificar, resolvendo problemas e reduzindo a complexidade de subsistemas, como, por exemplo, o recursal; dar todo o rendimento possível a cada processo em si mesmo considerado; e imprimir maior grau de organicidade ao sistema, dando-lhe, assim, mais coesão ${ }^{9}$.

A nova norma processual não se distancia das influências do neoconstitucionalismo, passando o processo a ser entendido como meio a se atingir a eficácia dos direitos fundamentais.

Dito isto, considerando como objeto do sistema a defesa das garantias constitucionais, aqui podendo denominá-las como devido processo legal e segurança jurídica, não se pode compreender como aceitável, muito menos correta a compreensão de que sob a égide do princípio da celeridade se possa derrogar norma processual devida e legalmente instituída.

É fato que a morosidade do Poder Judiciário é um problema a ser enfrentado, no entanto, a celeridade, não pode ganhar protagonismo de único ator no sistema processual. $\mathrm{Na}$ verdade, a celeridade é um pilar que vem sendo deteriorado a anos, cujos danos são decorrentes das falhas estruturais que afligem o Judiciário.

O afastamento da aplicação da norma processual da contagem de prazos nos Juizados Especiais feriu direitos constitucionalmente tutelados como o acesso à justiça, à ampla defesa, o devido processo legal, motivação das decisões em verdadeira afronta ao devido processo constitucional, ao Estado Democrático de Direito e concretização de direitos fundamentais.

Não se pode aceitar que princípios sejam usados como escudos para decisionismos ou mesmo permitir sua aplicação equivocada. Necessita-se, portanto, de uma abordagem crítica e apurada sobre o tema com o fito de evitar a discricionariedade, arbitrariedade e solipicismo judicial, questões que contribuem para o protagonismo judicial.

É claro, contudo, que os tribunais e juízes podem e devem basear-se em princípios para decidir, pois na sua essência e na utilização da moderna hermenêutica, os princípios não dão margem à discricionariedade, mas sim empregam harmonia ao sistema. Sendo necessário reconhecer que esse problema a ser enfrentado é um problema de democracia, que se forma na comunidade política e não da exclusiva subjetividade do intérprete, pois a atuação

$9 \quad$ Exposição de motivos do Código de Processo Civil de 2015.

Revista Cidadania e Acesso à Justiça | e-ISSN: 2526-026X | Porto Alegre | v. 4 | n. 2 | p. 96 - 115 | 
jurisdicional deve ocorrer dentro de limites, visando legitimar democraticamente as decisões judiciais.

Portanto, os princípios devem ser entendidos por meio de seu caráter normativo, não podendo ter mero papel retórico-corretivo, tampouco ser entendido como mandados de otimização, recheados de predicados morais ad hoc - típico das Teorias Argumentativas. Os princípios impõem seu conteúdo normativo a partir de uma convivência intersubjetiva que emana dos vínculos existentes na moralidade política da comunidade, de modo que de toda decisão se extrai (pelo menos) um princípio, o qual condicionará a próxima decisão. Neste sentido, o julgador fica limitado, exercendo, então, os princípios o papel de "amarra interpretativa" contra decisionismos. (MÜLLER; KÖCHE; STRECK, 2011)

A postura judicial de afastamento da regra processual de contagem de prazos, descrita no artigo 219 do Código de Processo Civil, sem que tenha sido declarada a inconstitucionalidade do instituto, fragiliza a segurança jurídica e reforça a imprevisibilidade no sistema de justiça, afrontando à divisão das funções estabelecidas pelo Constituinte.

A distribuição de competências constitucional reserva ao legislador a atribuição de estabelecer as normas que devem reger as decisões proferidas nos casos concretos e aos julgadores compete a aplicação da lei, excepcionando as hipóteses de incompatibilidade, dessa forma, a atuação judicial descrita no presente tema invade a esfera legislativa e ofende diretamente os artigos 2 e 5, inciso II, da Constituição Federal, presente também afronta ao devido processo legal decorrente do descumprimento do rito processual legalmente instituído e vigente, aplicando grave prejuízo ao contraditório e ampla defesa a todas as partes envolvidas nas demandas processadas nos Juizados Especiais pátrios.

De toda forma, compreende-se que nefastos são os efeitos da má aplicação teórica dos princípios e os prejuízos decorrentes dessa circunstância supera o grande problema da segurança jurídica, considerando que, por aproximadamente dois anos, teve-se a jurisprudência nacional dividida entre a aplicação ou não da norma processual, o que caracteriza a ocorrência de afronta aos princípios da separação de poderes, da legalidade e do devido processo legal.

A aplicação dos princípios deve atender aos pressupostos do Estado Democrático de Direito, decorrentes da Constituição dirigente, e o seu não atendimento custará caro à 
democracia em decorrência dos efeitos do panprincipiologismo, que são a discricionariedade e a arbitrariedade judicial.

\section{REFERÊNCIAS}

ALEXY, Robert. Teoria dos Direitos Fundamentais. Tradução de Virgílio Afonso da Silva. São Paulo: Malheiros Editores, 2007.

ALVES, André Luiz. Novo CPC (Lei 13.101/15): Objetivos e mudanças na organização do diploma. Estudos do Novo CPC [blog], 19 maio 2015. Disponível em: <

https://estudosnovocpc.com.br/2015/05/19/novo-cpc-lei-13-10515-objetivos-e-mudancas-naorganizacao-do-diploma/comment-page-1/>. Acesso em: 9 jun. 2018.

BASTOS, Celso; MEYER-PFLUG, Samantha. A interpretação como fator de desenvolvimento e atualização das normas constitucionais. In: SILVA, Virgílio Afonso da. [Org.]. Interpretação Constitucional. São Paulo: Malheiros, 2007.

BOLLMANN. Vilian. Aplicar o novo CPC a Juizados Especiais Federais para por condições. Disponível em: <http:// Conjur.com.br/2015-mai-31/aplicar-cpc-juizadosespeciais-federais-passa-condicoes $>$. Acesso em: 27 jul. 2018.

BRASIL. Constituição (1988) Constituição da República Federativa do Brasil. Texto constitucional promulgado em 5 de outubro de 1988. Brasília, DF, Senado, 1998. Disponível em: < http://www.planalto.gov.br/ccivil_03/constituicao/constituicaocompilado.htm>. Acesso em: 24 jul. 2018.

Decreto-lei n. 4.657, de 4 de setembro de 1942. Lei de Introdução às normas do Direito Brasileiro. Diário Oficial [da] República Federativa do Brasil, Brasília, DF, 4 set. 1942. Disponível em: <http://www.planalto.gov.br/ccivil_03/DecretoLei/Del4657compilado.htm>. Acesso em: 27 jul. 2018.

. Lei n. 12.153, de 22 de dezembro de 2009. Dispõe sobre os Juizados Especiais da Fazenda Pública no âmbito dos Estados, do Distrito Federal, dos Territórios e dos Municípios. Diário Oficial [da] República Federativa do Brasil, Brasília, DF, 22 dez. 2009. Disponível em: <http://www.planalto.gov.br/ccivil_03/_Ato2007-2010/2009/Lei/L12153.htm>. Acesso em: 25 jul. 2018.

. Lei n. 13.105, de 16 de março de 2015. Institui o Código de Processo Civil. Diário Oficial [da] República Federativa do Brasil, Brasília, DF, 10 mar 2015. Disponível em: <http://www.planalto.gov.br/ccivil_03/_Ato2015-2018/2015/Lei/L13105.htm >. Acesso em: 28 jul. 2018.

. Lei n. 9.099, de 26 de setembro de 1995. Dispõe sobre os Juizados Especiais Cíveis e Criminais e dá outras providências. Diário Oficial [da] República Federativa do Brasil, Brasília, DF, 26 set. 1995. Disponível em: <http://www.planalto.gov.br/ccivil_03/LEIS/L9099.htm>. Acesso em: 25 jun. 2018.

Revista Cidadania e Acesso à Justiça | e-ISSN: 2526-026X | Porto Alegre | v. 4 | n. 2 | p. 96 - 115 | 
CONSELHO DA JUSTIÇA FEDERAL. Enunciados. 2017. Disponível em: < http://www.cjf.jus.br/enunciados/>. Acesso em: 27 jul. 2018.

CONSELHO NACIONAL DE JUSTIÇA. Enunciados da Fazenda Pública. Disponível em: $<$ http://www.cnj.jus.br/corregedoriacnj/redescobrindo-os-juizados-especiais/enunciadosfonaje/enunciados-da-fazenda-publica>. Acesso em: 25 jun. 2018.

DANTAS, Ivo. Direito processual constitucional e direito constitucional processual: um debate em aberto. Revista Acadêmica, [online], v. 85, n. 2, 2013, p.200. Disponível em: https://scholar.googleusercontent.com/scholar?q=cache:fkgNpWgqlggJ:scholar.google.com/+ DANTAS,+Ivo.+Direito+processual+constitucional+e+direito+constitucional+processual:+u m+debate+em+aberto.+In:+Revista+Acad\%C3\% Aamica,+v.+85,+n.+2,+2013,+p.200.\&hl=pt -BR\&as_sdt=0,5. Acesso em: 21 jun 2018.

FIALHO, Arthur Monteiro Lins. A tutela sumária de direitos evidentes sob a ótica dos princípios constitucionais do processo. 2017. 138f. Dissertação (Mestrado em Direito) Centro de Ciências Sociais Aplicadas, Universidade Federal do Rio Grande do Norte, Natal, 2017. Disponível em: < https://repositorio.ufrn.br/jspui/handle/123456789/23712>. Acesso em: 21 jun. 2018.

FÓRUM NACIONAL DE JUIZADOS ESPECIAIS. Enunciados: Enunciados atualizados até o $43^{\circ}$ FONAJE. Disponível em: <http://www.amb.com.br/fonaje/?p=32〉. Acesso em: 22 jun. 2018.

FÓRUM PERMANENTE DE PROCESSUALISTAS CIVIS. Enunciados do Fórum Permanente de Processualistas Civis. 2017. Disponível em: <https://institutodc.com.br/wpcontent/uploads/2017/06/FPPC-Carta-de-Florianopolis.pdf>. Acesso em: 22 jun. 2018.

GRECO, Leonardo. Garantias fundamentais do processo: o processo justo. Disponível em: <http://egov.ufsc.br/portal/conteudo/garantias-fundamentais-do-processo-o-processo-justo>. Acesso em: 20 maio 2018.

KELSEN, Hans. Teoria pura do direito. Tradução de João Baptista Machado. 7. ed. São Paulo: Martins Fontes, 2006.

MARDEN, Carlos. A razoável duração do processo: o fenômeno temporal e o modelo constitucional processual. Curitiba: Juruá, 2015.

MARINONI, Luiz Guilherme; ARENHART, Sérgio cruz; MITIDIERO, Daniel. Novo curso de Processo Civil. São Paulo: Editora Revista dos Tribunais, 2015, v. 2.

MELO, José Maria de; TEÓFILO NETO, Mario Parente. Lei dos Juizados Especiais comentada. Curitiba: Juruá, 1997.

MÜLLER, Fabiano; KÖCHE, Rafael; STRECK, Lenio Luiz. Panprincipiologismo: O papel dos princípios em tempos de Constitucionalismo Contemporâneo. In: XII SALÃO DE

Revista Cidadania e Acesso à Justiça | e-ISSN: 2526-026X | Porto Alegre | v. 4 | n. 2 | p. 96 - 115 | 
INICIAÇÃO CIENTÍfICA, 12., 2011, Rio Grande do Sul, Resumo... Rio Grande do Sul: Pontífica Universidade Católica do Rio Grande do Sul, 2011. Disponível em: < http://ebooks.pucrs.br/edipucrs/anais/SIC/XII/XII/7/6/3/2/9.pdf>. Acesso em: 30 jul. 2018.

MÜLLER, Friedrich. Teoria moderna e interpretação dos direitos fundamentais: especialmente com base na teoria estruturante do direito. Anuário iberoamericano de justicia constitucional, n. 7, p. 315-327, 2003.

NIEMEYER, Sérgio. O novo CPC aplica-se supletivamente à lei dos Juizados Especiais. 2016. Consultor Jurídico [site], 23 maio 2016. Disponível em: < https://www.conjur.com.br/2016-mai-23/sergio-niemeyer-cpc-aplica-supletivamente-lei90991995>. Acesso em: 20 maio 2018.

PELEJA JÚNIOR, Antônio Veloso; OLIVEIRA, Humberto Santarosa de; O procedimento dos juizados especiais na perspectiva principiológica do novo Código de Processo Civil: contraditório e motivação das decisões como alicerces do devido processo legal. In: REDONDO, Bruno Garcia et. al. (coord.). Juizados Especiais. Salvador: Juspodivm, 2015, p. 71-100.

SILVA, Luis Virgilio Afonso da. Princípios e regras: mitos e equívocos acerca de uma distinção. Revista Latino-Americana de Estudos Constitucionais, Belo Horizonte, n. jan./jul. 2003, p. 607-630. Disponível em: < http://bdpi.usp.br/single.php?_id=001516601>. Acesso em: 20 jun. 2018.

STRECK, Lenio Luiz. Hermenêutica Jurídica e(m) crise: uma exploração hermenêutica da construção do Direito. 8. ed. Porto Alegre: Livraria do Advogado, 2009.

Verdade e consenso: Constituição, hermenêutica e teorias discursivas da possibilidade à necessidade de respostas corretas em Direito. Rio de Janeiro: Lumen Juris, 2014.

STRECK, Lenio Luiz. Zimermann, Schimidt, Streck e Otávio: todos contra o panprincipialismo. Consultor Jurídico [site], 5 mar. 2015. Disponível em: $<$ https://www.conjur.com.br/2015-mar-05/senso-incomum-balde-agua-fria-panprincipialismo-clausulas-gerais2>. Acesso em: 5 jun. 2018.

SUPREMO TRIBUNAL FEDERAL. OAB questiona contagem de prazos em dias corridos em juizados especiais. Notícias STF, 25 set. 2017. Disponível em: < http://www.stf.jus.br/portal/cms/verNoticiaDetalhe.asp?idConteudo=356751>. Acesso em: 25 jun. 2018. 